\title{
The concentration of $\mathrm{NaCl}$ soaking to decreasing cyanide levels in Gadung (Dioscorea hispida Dennst)
}

\author{
Dian Kresnadipayana ${ }^{1 a^{*}}$, Helmy Indra Waty ${ }^{2 b}$ \\ 1 Program Studi D-IV Analis Kesehatan, Fakultas IImu Kesehatan, Universitas Setia Budi Surakarta, Indonesia \\ 2 Program Studi D-III Analis Kesehatan, Fakultas IImu Kesehatan, Universitas Setia Budi Surakarta, Indonesia \\ a Email address: diankresna@setiabudi.ac.id \\ b Email address: helmyindrafx28@gmail.com
}

\section{HIGHLIGHTS}

Soaking $5 \% \mathrm{NaCl}$ in Gadung tubers containing cyanide can reduce cyanide levels by $99.70 \%$

\section{ARTICLE INFO}

\section{Article history}

Received date: February $28^{\text {th }}, 2019$

Revised date: Mei $03^{\text {rd }}, 2019$

Accepted date: Mei $17^{\text {th }}, 2019$

\section{Keywords:}

Cyanide

Gadung tuber

UV-VIS Spectrophotometry

\begin{abstract}
A B S T R A C T / A B S T R A K
Cyanide is one component contained in gadung tubers, and therefore, consuming gadung that contains more than $1 \mathrm{ppm}$ of cyanide can cause nausea and intoxication. This research aims to study the effect of concentration variation of $\mathrm{NaCl}$ soaking to the decrease of cyanide levels in gadung. This research is an experimental study with three treatment. Testing is only done once. Samples of gadung were soaked by $\mathrm{NaCl}(0 \%$ $1 \% 3 \% 5 \%$ ) for 3 days. Determination of cyanide content in gadung used the UV-Vis spectrophotometry method by adding Ninhydrin $0.1 \%$ in $\mathrm{Na}_{2} \mathrm{CO}_{3} 2 \%$ and $\mathrm{NaOH} 0.1 \%$ in the sample filtrate. Result of this research had shown that cyanide content in gadung before $\mathrm{NaCl}$ soaking was 4.42 ppm and after $\mathrm{NaCl}$ soaking $(0 \% 1 \% 3 \% 5 \%)$ were $3.52 ; 2.53 ; 0.43$ and $0.01 \mathrm{ppm}$, respectively.
\end{abstract}

This journal is an open-access article under the CC-BY-SA license.

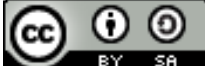

\section{${ }^{*}$ Corresponding Author:}

\section{Dian Kresnadipayana}

Program Studi D-IV Analis Kesehatan, Fakultas IImu Kesehatan

Universitas Setia Budi Surakarta, Indonesia

JIn. Letjen Sutoyo, Mojosongo, Surakarta, Indonesia.

Email: diankresna@setiabudi.ac.id

\section{INTRODUCTION}

Gadung plants are easy to grow in critical land without special care. ${ }^{1}$ Gadung plants grow wild in dry forestlands and can be cultivated in a home garden. This plant grows at an altitude of $850-1,200$ meters above sea level. ${ }^{2}$ Yogyakarta people process gadung tubers into chips. ${ }^{3}$ In Nusa Tenggara and Maluku, gadung tubers are consumed to substitute sago and corn during the dry season. ${ }^{2}$ Gadung is also found in other countries, and the people commonly use it for traditional medicine due to its efficacy in medication for illnesses, such as leprosy, dermatitis, abdominal spasms, as well as in the making process of oral contraception. ${ }^{4}$

Gadung tuber contains cyanide $\left(\mathrm{CN}^{-}\right)$, which has a negative effect on health. ${ }^{5}$ Results of the study have uncovered that fresh gadung tubers contain cyanide levels of $469.5 \mathrm{ppm} .{ }^{6}$ Consuming gadung tuber with a very high level of cyanide potentially causes 
nausea, motion sickness, even death. ${ }^{5}$ Based on SNI (Indonesian National Standard), the maximum limit of cyanide levels in food products is $1 \mathrm{ppm}^{7}$ The cyanide content $\left(\mathrm{CN}^{-}\right)$in gadung tubers needs to be minimised and eliminated by several processes so that the gadung tubers are safe and suitable for consumption.

Some alternative processing methods commonly carried out by the community are soaking tubers in water and smearing them with ash. However, the immersion method takes about 3-5 days and needs to be done so that it is considered less efficient. ${ }^{6}$ The process smearing with ash is inefficient because it requires many stages of treatments and takes up to 10 days. Another method is soaking gadung tubers into a salt solution. ${ }^{8}$ The use of salt solutions in soaking gadung tubers can cause differences in osmosis pressure inside and outside the material so that the osmosis diffusion process occurs from the inside part into the outside part of the dissolved material. ${ }^{8}$ When the concentration of the salt solution is too high, the osmosis process between water and solute (cyanide) gets faster.

Previous studies on gadung immersion used table salt and calcium solutions. The use of $\mathrm{NaCl}$ solution with various levels of concentration in the immersion in this research has never been applied in the previous research. The purposes of this study were to determine cyanide levels in gadung tuber samples before and after $\mathrm{NaCl}$ immersion and to determine the optimum concentration of $\mathrm{NaCl}$ which can reduce cyanide levels $\left(\mathrm{CN}^{-}\right)$ in gadung tuber samples.

\section{MATERIALS AND METHOD}

This research is an experimental study with three treatment. Testing is only done once.

\subsection{Tools and materials}

The tools used for determining cyanide levels in the sample: UV-vis spectrophotometric. Reagent materials needed: distilled water, $\mathrm{NaCl}(1 \%, 3 \%, 5 \%), \mathrm{CN}$ p $10 \mathrm{ppm}, 0.1 \mathrm{M} \mathrm{NaOH}, 0.1 \%$ Ninhydrin, and $2 \% \mathrm{Na}_{2} \mathrm{CO}_{3}$. The research material was gadung tuber obtained from Magetan Regency.

\subsection{Procedure}

\subsubsection{Sample Preparation}

Gadung tubers were cut $3 \mathrm{~mm}$ thick, pounded using mortar. The sample was then weighed five grams and added $10 \mathrm{ml}$ of distilled water. Next, it was filtered using Whatman filter paper no.42 until a clear filtrate was obtained. The filtrate was later tested qualitatively and quantitatively.

\subsubsection{Qualitative Analysis}

Qualitative analysis of cyanide was done by pipetting $2 \mathrm{ml}$ of gadung tuber filtrate to the test tube and adding $1 \mathrm{ml}$ of $0.1 \%$ ninhydrin solution in $2 \% \mathrm{Na}_{2} \mathrm{CO}_{3}$. Then, $15 \mathrm{drops}$ of $0.1 \mathrm{M} \mathrm{NaOH}$ were added and homogenized. Finally, the colour changes occurred. ${ }^{9}$

\subsubsection{Determination of Maximum Wavelength}

Solution $\left(\mathrm{CN}^{-}\right)$of $1 \mathrm{ppm}$ was pipetted as much as $2 \mathrm{ml}$ and put in the test tube. 1 $\mathrm{ml}$ of $0.1 \%$ ninhydrin solution was added in $2 \% \mathrm{Na}_{2} \mathrm{CO}_{3}$. Then, 15 drops of $0.1 \mathrm{M} \mathrm{NaOH}$ were added and homogenized. After the materials reacted, the colour changes occurred. The maximum wavelength was read using a UV-Vis spectrophotometer in the range 400 $-620 \mathrm{~nm} .^{9}$

\subsubsection{Determination of Sample Level}

Gadung tuber samples were cut with $3 \mathrm{~mm}$ thickness. The cuts were later soaked in $\mathrm{NaCl}$ solution (with concentration of $0 \%, 1 \%, 3 \%$, and $5 \%$ ) for three days. A total of 5 grams of refined gadung tuber samples were soaked in $10 \mathrm{~mL}$ of distilled water. Then, it 
was filtered using Whatman filter paper no.42 until a clear filtrate was obtained. Next, 2 $\mathrm{ml}$ of the filtrate is pipetted and put into the test tube. $1 \mathrm{ml}$ of $0.1 \%$ ninhydrin solution was added into $2 \% \mathrm{Na}_{2} \mathrm{CO}_{3}$. Finally, 15 drops of $0.1 \mathrm{M} \mathrm{NaOH}$ were added and homogenized. Finally, the colour changes occurred. ${ }^{9}$

\section{RESULTS AND DISCUSSION}

The results of the qualitative test on gadung tuber samples before immersion can be seen in Figure 1. The findings show that an identical purple/blue colour was formed both in the sample and in positive cyanide control.

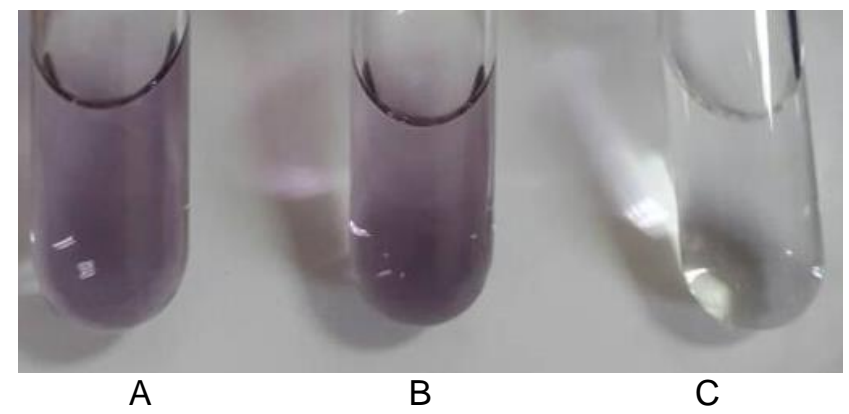

Description:

Figure 1. Qualitative Cyanide Test $\left(\mathrm{CN}^{-}\right)$

$A=$ gadung tuber sample before immersion

$\mathrm{B}=$ positive control (containing cyanide)

$\mathrm{C}=$ negative control (not containing cyanide)

Qualitative tests carried out by reacting the gadung tuber extract with $0.1 \%$ ninhydrin reagent in $2 \% \mathrm{Na}_{2} \mathrm{CO}_{3}$, and $0.1 \mathrm{M} \mathrm{NaOH}$ demonstrate that the sample of gadung tuber was identified containing cyanide $\left(\mathrm{CN}^{-}\right)$. The reaction between cyanide in gadung tuber with ninhydrin and $\mathrm{NaOH}$ resulted in purple/blue discolouration. The formation of purple/blue colour is obtained, exposing that ninhydrin forms red colour if reacted with cyanide. When $\mathrm{NaOH}$ is added, it forms a purple/blue colour.

Determination of the absorption value of a sample must be at the maximum wavelength so that the maximum value is obtained. The results of determination of the maximum wavelength using a UV-Vis spectrophotometer in the wavelength of $498 \mathrm{~nm}$. The determination of the calibration curve was obtained from the concentration of 10 ppm of cyanide stock solution $\left(\mathrm{CN}^{-}\right)$. The solution was then diluted to five concentrations, namely $1 \mathrm{ppm}, 2 \mathrm{ppm}, 3 \mathrm{ppm}, 4 \mathrm{ppm}$, and $5 \mathrm{ppm}$. The absorbance levels of the five concentrations of standard solutions were measured at a wavelength of $498 \mathrm{~nm}$. From the calibration curve, a regression equation $y=0.1273 \mathrm{X}+0.022$ was obtained.

The determination of initial levels of cyanide in gadung tuber samples before treatment was carried out three times. The absorbance obtained were: $0.572 ; 0.596$, and 0.586 . The average absorbance value was: 0.5847 . The value of cyanide concentration in gadung tubers before treatment was: $4.42 \mathrm{ppm}$. Cyanide content in gadung tuber samples was still above the SNI standard value with a maximum cyanide content of 1 ppm. $^{7}$

The results of immersion of gadung tubers with $0 \%, 1 \%, 3 \%$ and $5 \% \mathrm{NaCl}$ are demonstrated in Table 1. Gadung tuber samples were soaked for three days in $\mathrm{NaCl}$ solution $(0 \%, 1 \%, 3 \%$, and $5 \%)$, and purple/blue colour that was less bright than the colour before immersion treatment was obtained. This research shows that the cyanide level in the sample after treatment decreased. The absorbance value of the sample proves it before treatment, which was higher than that after immersion. 
Table 1. Determination of Cyanide Levels after Immersion with $\mathrm{NaCl}$ Concentration

\begin{tabular}{ccc}
\hline Variation of Concentration (\%) & $\begin{array}{c}\text { Average Cyanide Level } \\
(\mathrm{ppm})\end{array}$ & Decrease Percentage (\%) \\
\hline $\mathrm{NaCl} \mathrm{0}$ & 3.52 & 20.26 \\
$\mathrm{NaCl} \mathrm{1}$ & 2.53 & 42.77 \\
$\mathrm{NaCl} \mathrm{3}$ & 0.43 & 90.28 \\
$\mathrm{NaCl} \mathrm{5}$ & 0.01 & 99.70 \\
\hline
\end{tabular}

Based on research carried out, gadung tubers immersion using $3 \%$ and $5 \% \mathrm{NaCl}$ can reduce cyanide levels up to $90.28 \%$ and $99.70 \%$, with cyanide levels of $0.43 \mathrm{ppm}$ and $0.01 \mathrm{ppm}$. Therefore, it can be implied that the immersion of $3 \%$ and $5 \% \mathrm{NaCl}$ can reduce cyanide levels in gadung tubers to the safe limit of cyanide content in food products SNI (Indonesian National Standard) year 2015 which stipulates that the maximum limit of $\mathrm{HCN}$ level is $1 \mathrm{ppm} .{ }^{7}$ Some previous studies have revealed that the immersion result of gadung tuber using table salt $5 \%$ for three days is $66.99 \% .^{9}$ To compare two variables of the immersion with the same concentration $(5 \%), \mathrm{NaCl}$ is considered more effective because it can reduce the cyanide level-up to $99.70 \%$.

The decrease of cyanide level is due to the osmosis diffusion process when the immersion of gadung tuber using salt solution is carried out. ${ }^{10,11}$ The cyanide (HCN) compounds formed in gadung tuber undergo the osmosis diffusion and then bind to $\mathrm{Na}^{+}$ on $\mathrm{NaCl}$ to form $\mathrm{NaCN}$. According to the research in which gadung is immersed using $\mathrm{Ca}(\mathrm{OH})_{2}$, it is found that $\mathrm{Ca}^{2+}$ can bind to $\mathrm{HCN}$ to produce $\mathrm{Ca}(\mathrm{CN})_{2}$, which is easily dissolved in water. ${ }^{12}$ The difference in the immersion between $\mathrm{NaCl}$ solution and table salt solution is because table salt solution is composed of several types of salt. The most prominent component of the table salt is $\mathrm{NaCl}$ compound, but there are other compositions such as $\mathrm{CaSO}_{4}, \mathrm{MgSO}_{4}, \mathrm{MgCl}_{2}, \mathrm{KCl}, \mathrm{NaBr}$, and iodine. ${ }^{13}$ These new salt compounds cause the osmosis diffusion process in table salt immersion less efficient compared to that using $\mathrm{NaCl}$, which does not contain any other disturbing compounds. One of the factors that affect the osmosis reaction is that the molecules which are smaller than the centre line of the membrane hole will be more easily absorbed. Some salt compounds can be hygroscopic, that they absorb water from the tissue and damage cell walls and cause plasmolysis (cell membrane rupture due to lack of water). ${ }^{14}$

The practical application developed in this research is the use of table salt, especially $\mathrm{NaCl}$, which can serve as the alternative method to reduce the cyanide level in gadung tuber before the technological processing is carried out. Further studies regarding the importance of organoleptic of gadung tuber can be improved. The parameter of organoleptic aims to determine the colour, scent, and taste of gadung tuber after the immersion using $\mathrm{NaCl}$, for instance, by steaming, boiling, and frying. The processing of gadung tuber by frying can also reduce the cyanide level because the cyanide that is dissolved in water will evaporate with water particles during the frying process. ${ }^{15}$ The processing method by drying the tuber starch can also reduce some toxics. ${ }^{15,16}$ Several parameters that can be applied in further research are starch, water, ash, fibre, and nutrient in gadung tuber after treatment.

\section{CONCLUSION}

The results of the qualitative test show that gadung tubers contain cyanide. Quantitatively, the cyanide levels in gadung tubers before immersion treatment were $4.42 \mathrm{ppm}$. The optimum decrease in cyanide levels correlates with the immersion of $5 \%$ $\mathrm{NaCl}$ by the percentage of $99.70 \%$. 


\section{ACKNOWLEDGMENT}

I want to deliver sincere gratitude to Yayasan Setia Budi Surakarta through Institute of Research and Community Service (Lembaga Penelitian dan Pengabdian Masyarakat) of Setia Budi Surakarta for the Internal Research Grant (Hibah Penelitian Internal) as the source of funding in this research. Also, thank the assistant lecturer and laboratory technician who helped this research.

\section{REFERENCE}

1. Purnomo, B.S., Daryono, Rugayah, dan Sumardi. Studi Etnobotani Dioscorea sp. (Dioscoreaceae) dan Kearifan Budaya Lokal Masyarakat di Sekitar Hutan Wonosadi Gunung Kidul Yogyakarta. Jurnal Natur Indonesia. 2012;14(3) : 191198.

2. Lembaga Ilmu Pengetahuan Indonesia. Ubi-Ubian. 1990. Bogor: Balai Pustaka

3. Sastrapradja, S.D. Perjalanan Panjang Tanaman Indonesia. 2012.Jakarta: Yayasan Pustaka Obor Indonesia.

4. Badan Pengawas Obat dan Makanan. Mengenal Gadung dan Resiko Keracunannya. 2015. Sentra Informasi Keracunan (SIKer) Nasional.

5. Sumunar, S.R. dan Estiasih, T. Umbi Gadung (Dioscorea hispida Dennst) Sebagai Bahan Pangan Mengandung Senyawa Bioaktif. Jurnal Pangan dan Agroindustri 2015;(1): 108-112.

6. Harijono, Sari, T.A., dan Martati, E. Detoksifikasi Umbi Gadung (Dioscorea Hispida Dennst.) Dengan Pemanasan Terbatas Dalam Pengolahan Tepung Gadung. Jurnal Teknologi Pertanian, 2008;(2):75-82.

7. Badan Standarisasi Nasional. Air dan air limbah - Bagian 77 : Cara uji sianida (CN )secara spektrofotometri. 2011. SNI 6989.77:2011.

8. Pambayun, R. Hydro cianic acid and organoleptic test on gadung instant rice from various methods of detoxification. Prosiding Seminar Nasional Industri Pangan. 2000. Perhimpunan Ahli Teknologi Pangan (PTPAI) Surabaya.

9. Hardjo, M. Tepung Gadung (Dioscorea hispida Dennst) Bebas Sianida dengan Merendam Parutan Umbi dalam Larutan Garam. Jurnal Matematika, Sains, dan Teknologi, 2005;(2) : 92 - 99.

10. Surleva, A.R., Sabina, B., dan Todorova, E.V. A Study on Ninhydrin Reaction With Week Acid Dissociable Cyanide And Its Application For Toxic Cyanide Determination. Science Journal of Analytical Chemistry, 2014;2(1):1-6.

11. Drochioiu, G.I., Sandu, dan Gradinaru, E. Ninhydrin-Based Forensic Investigations:Il. Cyanide Analytical Toxicology. International Journal of Criminal Investigation, 2016;1(4): 213-226.

12. Suismono dan Prawirautama. Kajian Teknologi Pembuatan Tepung Gadung dan Evaluasi Sifat Fisikokimianya. Prosiding Seminar Teknologi Pangan dan Gizi. PAU Pangan dan Gizi UGM. 1998. Yogyakarta.

13. Muryati. Pemisahan dan Pemanfaatan Bitern Sebagai Salah Satu Upaya Peningkatan Pendapatan Petani Garam. Buletin Penelitian dan Pengembangan Industri, 2008;2(2): 5-14.

14. Pursudarsono, F., Rosyidi, D. dan Widati, A.S. Pengaruh Perlakuan Imbangan Garam dan Gula terhadap Kualitas Dendeng Paru-Paru Sapi. Jurnal IImu dan Teknologi Hasil Ternak, 2015;10(1): 35-45.

15. Djaafar, T.F., Rahayu, S., dan Gardjito, M. Pengaruh Blanching dan Waktu Perendaman dalam Larutan Kapur terhadap Kandungan Racun pada Umbi dan Ceriping Gadung. Penelitian Pertanian Tanaman Pangan, 2009;28 (3): 192-198.

16. Koswara, S. Teknologi Pengolahan Umbi-umbian. Tropical Plant Curriculum (TPC) Project. Southeast Asian Food and Agricultural Science and Technology (SEAFAST) Center Research and Community Service Institution. 2013. Institut Pertanian Bogor. 